\title{
Larissa Gordon
}

\section{Partnering for success Using mini grants to foster faculty/librarian collaborations}

O ne desire that instruction librarians share is the desire to move beyond the traditional one-shot bibliographic instruction session and toward a more collaborative and course integrated model of information literacy. Numerous articles in the library literature have described such collaborative efforts between librarians and faculty members, and recently an entire book has been devoted to this topic. ${ }^{1}$ Clearly, this type of collaboration is the current trend in information literacy, and this trend has emerged for several powerful reasons. Collaborative projects can help to enhance the image of the library, create enthusiastic library champions among the faculty, and further the success of an information literacy program. However, the truth is that in-depth collaboration is not always easy to achieve, which is why Arcadia University's Landman Library made the decision to institute an internally funded Information Literacy Collaborations grant program in fall 2008.

\section{Grant program options}

Awarding faculty a monetary incentive to collaborate with librarians is not a new idea. Many libraries have paid faculty to work on collaborative projects as part of much larger externally funded information literacy grants. ${ }^{2}$ Another strategy has been to pay faculty to attend group professional development workshops. These types of workshops are designed to give faculty the basic skills they need to understand information literacy as well as teach them how to begin the process of embedding information literacy skills in their courses. ${ }^{3} \mathrm{~A}$ third option, one that is recommended by ACRL on its information literacy Advocacy
Web site, is the use of internally funded faculty professional development grants that can be used to promote in-depth collaborations between faculty and librarians. ${ }^{4}$ After conducting research and consulting with other academic libraries, Landman Library decided to acquire funds to start this third type of grant program. We are by no means the first library to develop such a program. ${ }^{5}$ However, information in the library literature about internally funded grant programs seems to be scarce, and while the ACRL Web site does briefly mention this idea, it does not go into any detail about how to begin such a program, nor does it talk about how a program such as this might function. We hope to bridge this gap with a description of the process we experienced in implementing our grant program. Currently, we are in the beginning stages of the collaboration process, so critically evaluating the types of collaborations that arise from this effort will remain the task of another article. However, through our experiences thus far, we have already learned a great deal about the process of developing and organizing the grant award itself, as well as the types of collaborations that are possible with such a program.

\section{Program rationale}

Seeking internal funding is much less time consuming than applying for and managing an outside grant, especially a large one, which might require the participation of multiple libraries to be successfully funded. Building

Larissa Gordon is reference librarian at Arcadia University, e-mail: gordonl@arcadia.edu

() 2010 Larissa Gordon 
our grant program using a one-on-one collaboration model also allows us to work more closely with individual faculty members, and to develop a stronger personal relationship with our faculty than might otherwise occur in a group setting. Even though we will only be able to reach a few faculty members each year, our hope is that each person with whom we work will then talk with their colleagues, and that over time a culture of information literacy will permeate the campus community. This model may not work as well for a larger institution; however, Arcadia's small size and closely knit community favor this strategy.

\section{Process reflections}

The first step in establishing this program was to talk to the university administration to secure funding. In our case, university faculty development funds were available to support our program. Once funding was found, the library issued a call in November 2008 to the entire Arcadia full-time faculty (90) inviting them to apply for our Information Literacy Collaborations Grant, with applications due the week before winter break.

In retrospect, starting the application process earlier in the semester might have enabled more faculty to apply, because we would not have been competing for their time with final examinations and grade submissions. However, as it was, we received 16 applications, which actually exceeded our expectations for the first year of the program. The grants we ultimately awarded varied widely by department, and included both undergraduate- and graduate-level courses. In the end, we had so many excellent applications that the library decided to fund two additional grants itself, bringing the total number of projects we to six. What follows are a few process recommendations based on our experience implementing this program.

- Format the grant application with care and ensure that the decision making process is transparent. Taking time early on to reflect about how your institution will evaluate grant applications will make the process much easier in the long run. Include language in the grant application that discusses restrictions on who may apply or that reveals any courses which may receive preferential treatment. A new general education curriculum had recently been implemented at Arcadia, so grant applications that met a general education curricular designation were given first consideration.

Another suggestion is to remember to note on the application form the person responsible for making the final decision about awards and what criteria they will use to make those choices. Will the library director decide alone? Will there be a team of librarians making the choice? Will other faculty members be involved in the process? Finally, make sure that all the decision makers fully understand the application criteria. Do faculty members need to have a well-developed idea coming into the process, or is it enough that they are interested in learning more and understand that working with a librarian can benefit their students? Do you want faculty to already have a good understanding of what information literacy is before work on the project begins or can the grant process work to impart that knowledge to faculty?

- Advertise. Part of the purpose of this grant is to raise the profile of information literacy on campus, so make sure to advertise both the grant application process and the award winners in every venue possible. Approaching faculty members and encouraging them to apply can also be a great idea. Just make sure they are really interested and willing to think carefully about submitting an application. Avoid the impulse to help them too much when they are completing the application. Better applications come from self-motivated faculty who take the time to think about information literacy and how they can integrate information literacy skills into their courses.

- Include reporting and meeting requirements. At Arcadia, faculty who receive a stipend from the university professional development fund are required to submit a report when their project is completed. We kept this final report as a requirement for our grant project and also added an interim report, which was due at the end of the course-planning 
phase. Even if it is not strictly necessary at your institution, some form of reporting is an excellent idea because it allows you to gather data to support your program. The reports can also add structure to the grant program by setting goals for the collaborative process. Consider asking faculty to report on their progress in developing specific information literacy outcomes and tying those outcomes directly to assignments. Giving faculty a space to reflect on the collaborative process with their liaison librarian can also be helpful, because it can provide insight into ways that the collaborative process can be improved.

It is also important to gather assessment data in the final report about student information literacy learning. In addition to reporting requirements, establishing a set meeting schedule between librarians and faculty members can also help to ensure that adequate time is devoted to the collaborative process. At Arcadia we plan to require that our next set of grant winners meet with their librarian at least two times a month during the spring and summer semesters.

\section{Faculty understanding of information literacy}

After our grants were awarded, but before any collaborative work began, the library held a lunch meeting with the faculty and librarians who would be working together on a grant project during the coming year. By keeping our questions few and open-ended, we were able to elicit responses that revealed much about faculty impressions of information literacy and their expectations for this grant program.

During our initial discussions it seemed as if faculty understanding of information literacy was limited. This was surprising, especially since we had included a link to ACRL's information literacy page on the grant application form. However, once the conversation began, faculty, aided by occasional comments from librarians, helped to inform each other's understanding of information literacy. It turned out that the group's collective knowledge about information literacy was actually fairly sophisticated, and that faculty members were very aware of the types of skills they would like to see improved in their students. One faculty member even expressed surprise at how broad the umbrella of skills related to information literacy really was.

Some traditional information literacy ideas, such as source evaluation, were discussed, but there were a few more interesting comments made by faculty about what they hoped to teach their students that I wish to address here.

One faculty member emphasized his desire to instill a sense of inquiry into his students about the research process. He felt that research should foster a sense of excitement and curiosity, motivating students to find out more about their topic. According to this faculty member, research should ultimately support student creative endeavors and help students to change and to grow.

This idea was very powerful and was quickly echoed by the other faculty members at the meeting. Another concept that quickly took root among the faculty was the idea of the importance of the library as a physical space that students should experience. Faculty wanted to bring their students to the library, and one faculty member even expressed interest in teaching his class in the library. He hoped that students would respond to the library's atmosphere and that their curiosity would be ignited during the process, allowing them to fully experience and appreciate the rich resources the library had to offer: the physical, human, and electronic.

Ultimately, this collaboratively created understanding of information literacy will be a much more powerful influence on faculty than would a definition that was imposed by librarians from the outside. During the meeting, faculty were able to relate information literacy concepts with their own experiences in the classroom and the conversations they had with each other helped to further emphasize how librarians can help improve the student learning experience. This meeting also gave the librarians an opportunity to talk about what we have done in the past and to provide faculty with examples of the many ways that 
we can help teach information literacy skills to their students in the future.

One of our most surprising moments during the meeting occurred when one of the faculty members asked if we were getting extra compensation for the work we would be doing with them (we're not!). Hearing this comment helped us to understand that faculty really did see the value in what we were trying to do and that they were really willing to work in a collaborative way to build something new for their courses and their students. More work will still need to be done between the individual grant winners and their liaison librarians to help faculty come to a full and complete understanding of information literacy, but an important foundation was developed during the meeting, which we hope will translate into successful projects and enjoyable collaborative experiences for everyone involved.

\section{Initial collaborations}

The type of collaborative efforts that have resulted thus far from the grant program go far beyond anything that we have traditionally achieved during our talks with faculty who schedule one-shot instruction sessions. The inherent structure of the program and the formality of the reporting requirements also foster a much more intensive and organized collaboration than what has occurred in the past between faculty and librarians who have talked with each other about information literacy instruction. In addition to increasing faculty knowledge about information literacy through group discussion, librarians have talked individually with their faculty members about information literacy and shared research articles with them from the library literature. Librarians have taught faculty members more about library resources and some online resources (such blogs and wikis) that are available to their students, discussing with them ways that they can use these resources in class for research and assignment design purposes. Faculty and librarians have worked together to analyze course syllabi for information literacy opportunities, to develop information literacy outcomes for each course, and to formally link those outcomes to assignments that will assess student learning. Librarians have also worked intensively with faculty to create new assignments or to modify existing assignments to better teach information literacy concepts to students.

A second group meeting was held with all grant winners early in the summer, which allowed faculty and librarians to share their assignment ideas and collaboration strategies with each other, a process that hopefully energized each group and brought new ideas to the table during the planning phase of the grant process.

At the time this article is being written, our faculty and librarians are just getting ready to begin teaching their courses in the fall. In a few months time, we should have student learning assessment data that can help shed light on how successful the collaborative projects have been. However, we have already succeeded with this project in creating closer connections with faculty and in creating champions for information literacy on our campus.

\section{Notes}

1. Dick Raspa and Dane Ward, eds, 2000 The Collaborative Imperative: Librarians and Faculty Working Together in the Information Universe (Chicago: ACRL).

2. For example, large Mellon Foundation grants were received by the CTW consortium and the Five Colleges of Ohio consortium. Part of the grant funding was used in both of these instances to support faculty/librarian collaborative projects.

3. Jennifer Little and Jane Tuten, "Strategic Planning: First Steps in Sharing Information Literacy Goals with Faculty Across Disciplines," College and Undergraduate Libraries 13, no. 3: 113-23.

4. ACRL Information Literacy: Advocate for information literacy, see www.ala.org/ala /mgrps/divs/acrl/issues/infolit/professactivity /advocate/advocateil.cfm

5. For example, the Lafayette College Library has supported such a program since 2002, see library.lafayette.edu/instruction /infolitgrants. $\boldsymbol{n}$ 